Journal of Science and Technology, Vol. 32, No. 1 (2012), pp 56-67 56

(C) 2012 Kwame Nkrumah University of Science and Technology (KNUST)

http://dx.doi.org/10.4314/just.v32i1.7

RESEARCH PAPER

\title{
PERCEPTIONS OF UNDERGRADUATE CONSTRUCTION STUDENTS ON INDUSTRIAL TRAINING IN GHANA
}

\author{
J. Ayarkwa, K. Agyekum and E. Adinyira \\ Department of Building Technology, KNUST, Kumasi, Ghana \\ ayarkwajosh@yahoo.comor jayarkwa.cap@knust.edu.gh
}

\begin{abstract}
:
Ghanaian universities' curricula, which have provisions for industrial training (IT), have not made the expected impact on graduates to meet the expectations of the construction industry. This paper assesses the perceptions of undergraduate construction students on IT in Ghana, its challenges and possible measures to overcome them. The study employed a structured questionnaire survey of 185 final year construction students of the Kwame Nkrumah University of Science and Technology (KNUST), Kumasi, Ghana. Data analysis was based on mean scores of factors evaluated and the t-test was used to assess the significance of the differences between students' performance before and after undertaking IT. Students are of the perception that IT exposes them to real work environment and increases their job prospects among others. Students' satisfaction level with their performance on personal attitude, communication and work attitude significantly improved after undergoing IT. Students are, however, not satisfied with their departments' involvement in IT, particularly, with regards to placement and monitoring. Stressful placement processes and financial strain on students are some of the challenges identified.
\end{abstract}

Keywords: Industrial training, perception, construction graduates, Ghana.

\section{INTRODUCTION}

Rapid growth of infrastructural development in Ghana recently has increased job opportunities for many graduates of construction-related programmes. Until recently, construction students were readily accepted into the Ghanaian construction industry. However, with the increasing number of graduates produced every year, the industry now has to choose graduates with sufficient competence level and excellent qualification. The universities have the responsibility of producing graduates who meet the expectation of the construction industry. As an assurance that the performance of construction students is up to the required standards, preparation and exposure of students to industrial training (IT) is necessary in any professional education training programme (Osman et al., 2008). IT is one of the essential curriculum requirements of any technical institution (Bansal et al., 2010; Pillai and Yusoff, 2007). According to Nambudiripad (2003), students graduating from universities are like uncut diamonds and look useless like trifles, but when 


\section{Ayarkwa et al.}

given proper training they dazzle forth in all their glory.

Bansal et al. (2010) assert that although Universities' curricula have provision for IT and various training schemes are in force, especially for professional courses, some IT programmes have not made considerable impact and need quick redress. It has become a competitive endeavour for students, and placement is akin to job placements, making it stressful to students (Bansal et al., 2010; Pillai and Yusoff, 2007). If students are to meet the skills requirements of an ever-changing labour market, adequate resources need to be invested in appropriate forms of work experience and in building up transferable skills (Mihail, 2006).

To confirm the importance of IT in Ghana, Duodo (2006) noted that, there have been ongoing discussions with Ghana Employers Association and Association of Ghana Industries to formalize industrial training programmes. The IT programme prepares students for the labour market. It has become an innovative phenomenon in human resource development and training in Ghana. IT is thus, an important strategy to expose students to real life work situation and to equip them with the necessary skills so that they would be job-ready when they graduate.

Although IT plays an important role in preparing qualified future professional manpower, little research has been done to address issues which seek to improve the effectiveness of IT programmes, especially, for construction students in Ghana. This study therefore assesses the perceptions of undergraduate students from the Department of Building Technology and the Department of Architecture of the Kwame Nkrumah University of Science and Technology (KNUST) on IT programmes. It also identifies challenges to IT and possible measures to enhance its effectiveness.

The value and objectives of IT are well documented in the literature (Rahman et al., 2009;
Osman et al., 2008; Connor and Shaw, 2008; Pillai and Yusoff, 2007; Mihail, 2006; Teoh, 2006; Wasonga and Murphy, 2006; Callanan and Benzing, 2004; Fallows and Steven, 2000). Rahman et al. (2009) and Osman et al. (2008) urged graduates to prepare themselves and improve their personal attitude, work attitude, communication, leadership and other soft skills before they graduate. Fallows and Steven (2000) stated that employers need graduates to contribute immediately on starting work, and graduates need to develop their skills within a short time towards the competence level set by the employer. IT is reported to improve job opportunities for students since it allows them to refine their job skills and work values, focus on their career choices, directly access job sources, and impress potential employers (Mihail, 2006; Callanan and Benzing, 2004). It is a positive developmental experience for university students to improve their ability to secure career-oriented positions (Callanan and Benzing, 2004), leadership skills (Wasonga and Murphy, 2006), specialist knowledge, information technology, time management, and teamwork (Mihail, 2006). IT also helps to develop the student's communication skills that include daily interaction within the working environment and technical writing (Connor and Shaw, 2008; Mihail, 2006). Work experience is reported by Garavan and Murphy (2001) to provide credible means for softening the reality shock of transitioning from the world of academics to the world of work.

The objectives of IT are to expose the students to construction practice specific to their field of specialization, to the nature of the industry selected, and to expose the students to their responsibilities in the construction profession (Rahman et al., 2009). It provides opportunities for undergraduates to apply what they have learnt at the university, provides on-the-job training and real-life job experience, making them more employment ready (Rahman et al., 2009; Pillai and Yusoff, 2007). IT also makes students more aware of the needs and expectations of the industry and shape graduates who 
are "energetic and action-oriented" (Rahman et al., 2009; Pillai and Yusoff, 2007).

IT is an extremely valuable component of university education, especially for professional courses (Bansal et al., 2010; Pillai and Yusoff, 2007). Academic institutions organize and promote the placement of students in private enterprises and other organizations to foster work experience so that students will attain the necessary skills to supplement their theoretical training (Mihail, 2006). While students are still in the university, IT helps them develop a core of global market skills such as communication and time management skills, better selfconfidence and better self-motivation, that are now considered requirements (Gill and Lashine, 2003). Students undertaking IT are supervised by their university lecturers as well as industry supervisors, and students have to prepare and submit written reports on their IT experience (Pillai and Yusoff, 2007). Connor and Shaw (2008) emphasized the need for higher educational institutions to continue to strengthen its links with industry and commerce, not only to give graduates the skills which employers value but also to make sure that students are aware of what is happening in the labour market and what employers are seeking.

In analyzing the role of the university in IT, Mihail (2006) stated that modern knowledge economy requires a leap in graduates' skills, and educational institutions are expected to implement innovative reforms to provide their students with skills needed by "high performance" firms. The importance of making the most of communication opportunities between training institutions and employers cannot be underestimated. The flow of supply and demand information between training institutions and employers and the integration of that information into training programmes are at the crux of providing strong support to a country's industrial workforce needs (Chileshie and Haupt, 2006). Currently, there are growing concerns about the perceived mismatch be- tween industry needs and demand and skills of the graduates produced by higher education institutions (Haupt, 2003). Haupt (2003) again states that there is a gap between what employers appear to want and what higher education provides.

\section{RESEARCH METHODOLOGY}

The study involved a comprehensive review of published works and electronic presentations on IT and a questionnaire survey of undergraduate construction students. The survey instrument employed was a structured questionnaire. The questionnaire was administered to all 185 final year students of the Bachelor of Science Building Technology and Architecture programmes at KNUST. To maximize the response rate, face-to-face questioning approach was used to administer the questionnaire. Out of the total of 185 questionnaires administered to all final year students of the Departments of Building Technology and Architecture, 125 were retrieved and used in the analysis, giving a response rate of $68 \%$, considered sufficient for the study (Moser and Kalton, 1993). The study assumed that final year students had undertaken industrial training at least once and would have a higher level of experience with industrial training and could provide objective and accurate industrial training perspectives.

Closed questions were mainly used in the survey since it is considered likely to reduce bias in the question and answer processes (Roberts, 2007). However, open-ended questions were used where respondents were asked to suggest areas of improvement and possible solutions to challenges to IT. The questionnaire comprised of three main sections as follows.

Section one focused primarily on

- the profile of the respondents;

- $\quad$ their experience with IT;

- reasons for not undertaking IT; and

- issues on placement for IT.

Section two sought for

- factors motivating students to undertake 


\section{Ayarkwa et al.}

IT;

- $\quad$ students' perceptions on benefits of IT;

- Students perceptions on performance before, during and after IT; and

- $\quad$ IT monitoring system.

Section three focused on

- challenges of IT and measures to overcome such challenges.

For evaluation of factors motivating students to undertake IT, respondents were asked to score the factors on a Likert scale of 1 to 5 , where score ' 1 ' = strongly disagree, score ' 2 ' = disagree, score ' 3 ' $=$ neutral, score ' 4 ' $=$ agree, and score ' 5 ' $=$ strongly agree. For evaluation of respondents' perception before, during and after undergoing IT, they were asked to score their satisfaction levels on the Likert scale of 1 to 5 , where score ' 1 ' $=$ most unsatisfactory, score ' 2 ' = unsatisfactory, score ' 3 ' = neutral, score ' 4 ' = satisfactory, and score ' 5 ' = most satisfactory. From the various scores it was possible to rank the factors according to their mean scores. The one sample t-test at 5\% significance level was used to determine whether students' satisfaction with their performance on each attribute in three categories (personal attitude, communication and work attitude) increased after IT. The one-sample t-test was used to compare the mean performance of the students before and after IT. The null hypothesis was that there was no significant difference in the students' performance before and after the IT. Any significant improvement in performance could be attributed to the IT.

\section{RESULTS AND DISCUSSION Respondent's Profile}

Sixty-five percent $(65 \%)$ of the respondents to the survey were from the Department of Building Technology and 35\% from the Department of Architecture (Table 1). About $85 \%$ of the respondents in Table 1 had undertaken industrial training at least once and about $15 \%$ had not undertaken industrial training at all. The most common reasons for not undertaking industrial training included, 'industrial training was not compulsory', 'no remuneration' and 'application for placement was stressful'.

\section{Placement for industrial training}

Figure 1 shows that about $91 \%$ of the respondents had worked as trainees either in a consultancy or in a construction organization or both. These organizations were directly in the respondents' chosen fields of specialization. However, $4 \%$ of the respondents had worked in either the environmental agency or the banking sector, and $3 \%$ and $1 \%$ of the respondents had worked in the transportation and energy sectors respectively.

Figure 2 shows the method by which respondents received their placement for training in the industry. Forty-two percent $(42 \%)$ of the respondents received placement through their relatives and $38 \%$ through their friends. Fourteen percent $(14 \%)$ of the respondents, however, received placement through their own efforts and only 5\% received placement through their respective teaching departments.

This result suggests very little involvement of the teaching departments in the placement of prospective trainees.

Figure 3 shows that the major contribution of the teaching departments was issuance of introductory letters to prospective trainees (94\%). Issuance of introductory letters only does not contribute much to students' chances of obtaining placement for their IT. This is corroborated by the fact that only $60 \%$ indicated their satis-

Table 1: Frequency of respondents by department

\begin{tabular}{lll}
\hline Respondents' Department & No. of Response & Percentage (\%) of Response \\
\hline Architecture & 44 & 35 \\
Building Technology & 81 & 65 \\
Total & 125 & 100 \\
\hline
\end{tabular}




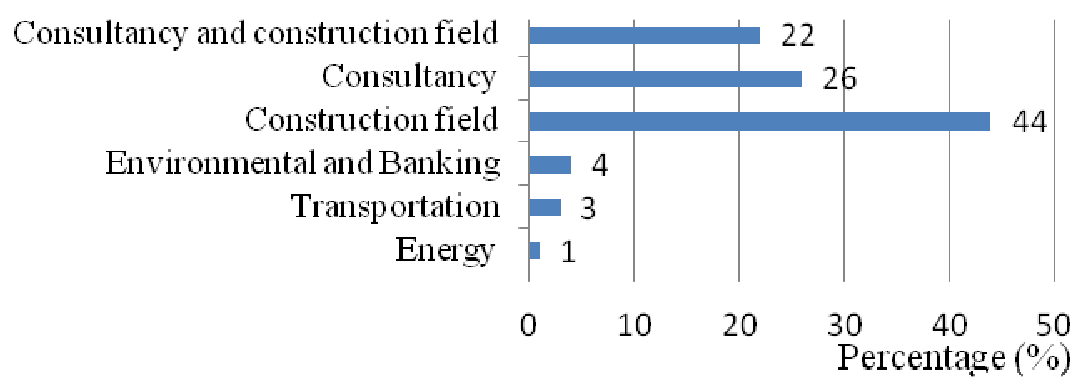

Fig. 1: Respondents' industrial training field

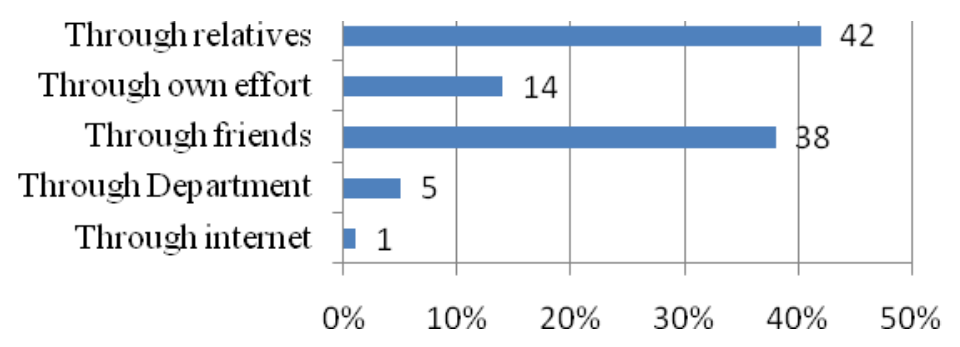

Fig. 2: Respondents' means of placement

faction with the current placement method (Fig. 4).

Mihail (2006) stated that academic institutions should actively organize and promote the placement of students in private enterprises and other organizations to foster work experience so that students will attain the necessary skills to supplement their theoretical training.

Gill and Lashine (2003) also emphasized that while students are still in the university, it should be the responsibility of the university to organize IT since it can help students develop a core of global market skills such as communication, time management, better selfconfidence, and better self-motivation that are now considered requirements for employment. Motivational factors for industrial trainingFactors that motivate respondents to undertake
IT include 'exposure to real working environment' and 'increase job prospects' (Table 2). Mean scores of all the motivating factors evaluated except 'meeting requirements of the Department' are significantly greater than the neutral score of $3.00(p=0.05)$ when the t-test was applied. Thus, the respondents agree that 'exposure to the real work environment' and 'increase in job prospects' are the first and second major factors motivating them to undertake IT. Other motivating factors include "provision of knowledge and guidance in choosing job after graduation', 'confidence in terms of job qualification', and 'improvement of communication skills'. The respondents, however, disagree that 'meeting the requirements of the department' is a motivating factor to undertake IT, suggesting that IT is not enforced by any of the two departments studied. Rahman et al. (2009) emphasize the importance of IT to pro- 
61 Ayarkwa et al.

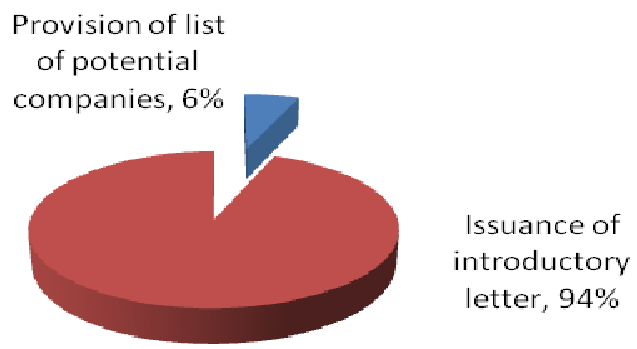

Fig. 3: Percentage contribution of Departments to respondents' placement

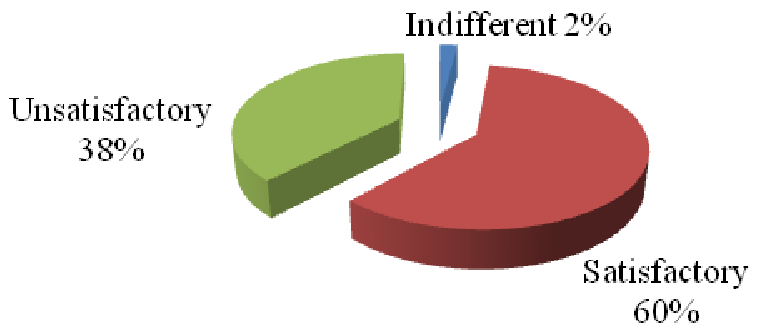

Fig. 4: Respondents' perceptions on the current method of placement

fessional education by stating that it is now a compulsory course for every student in the Civil and Structural Engineering Department in the Universiti Kebangsaan Malaysia (UKM). Bansal et al. (2010) and Pillai and Yusoff (2007) stressing the importance of IT to construction education, assert that universities' curricula have provision for IT, especially for professional programmes. To confirm the importance of IT in Ghana, Duodo (2006) noted that there have been on-going discussions with Ghana Employers Association and Association of Ghana Industries to formalize IT programmes.

Perceptions on benefits of industrial training

Table 2: Factors that motivate students to undergo industrial training

\begin{tabular}{llll}
\hline Motivating Factor & Mean & Std. Dev. & Rank \\
\hline To be exposed to real working environment & 4.39 & 0.610 & 1 \\
To increase job prospects & 4.00 & 0.663 & 2 \\
$\begin{array}{l}\text { To provide knowledge and guidance in choosing job after } \\
\text { graduation }\end{array}$ & 3.92 & 0.759 & 3 \\
To increase confidence in terms of job qualification & 3.69 & 0.879 & 4 \\
To improve communication skills & 3.62 & 0.936 & 5 \\
To meet requirements of the department & $* 2.32$ & 1.157 & 6 \\
\hline
\end{tabular}

*The t-test indicates that the mean score is not significantly greater than $3.00(p=0.05)$ 
About $95 \%$ of the respondents were of the perception that completion of IT could increase their job prospects, $93 \%$ also perceived that IT could provide more confidence in terms of job qualification, and $90 \%$ perceived that IT could provide more knowledge and guidance in their job selection after graduation (Fig. 5). Eightythree percent $(83 \%)$ of the respondents also perceived that it provides a platform for the industry to evaluate their future employees.

Thus, majority of students were of the view that IT was beneficial and allowed the acquisition of job relevant skills. Improved communication skills through daily interaction with the working environment and improved leadership skills are attributes that industrial training could help improve in order to instill more confidence in terms of job qualification (Connor and Shaw, 2008; Mihail, 2006). The results of the study are thus in line with findings from the literature. Callanan and Benzing (2004) found that IT improved the individual's career decisionmaking, and Rahman et al. (2009) and Osman et al. (2008) also found that IT served as a platform for the development of students' communication skills.
Undergraduate industrial training...

Perceptions on performance before and after industrial training

Mean scores of students' satisfaction with their performance on each of the 17 attributes in the three categories (personal attitude, communication and work attitude) before and after undertaking IT are presented in Table 3. The differences between mean scores (i.e. mean score gaps) of students' satisfaction with their performance on each of the 17 attributes before and after undertaking IT are also presented in Table 3. The one sample t-test at 5\% significance level showed that there are significant differences between mean scores of all attributes before and after undertaking IT. Students' satisfaction with their performance on each attribute in the three categories increased after the IT. This indicates that the respondents perceived their personal attitude, work attitude and communication skills to have satisfactorily improved through IT. On personal attitude, the mean score gap shows that students' selfconfidence is perceived to have most significantly improved after the IT. With regards to communication, oral communication skills most significantly improved, whilst their subject knowledge also significantly improved after undertaking IT.

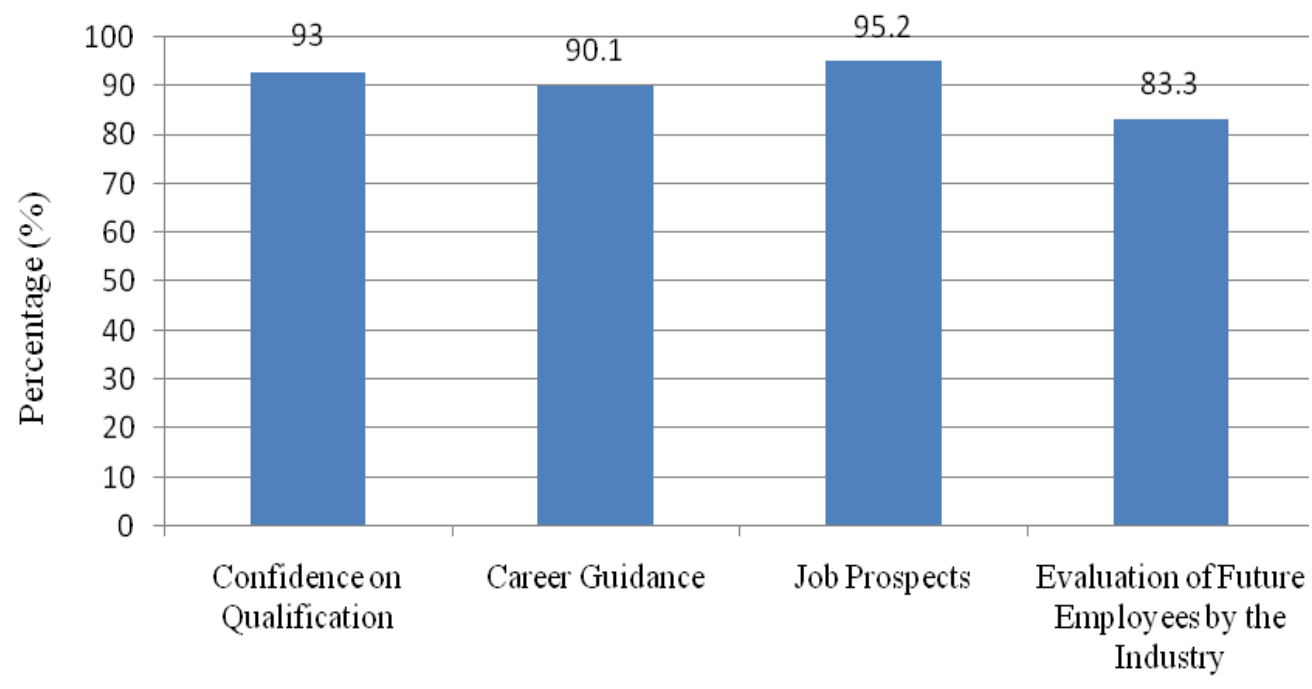

Fig. 5: Respondents' perception on the benefits of industrial training 


\section{Ayarkwa et al.}

The results are consistent with the findings of Rahman et al. (2009) and Osman et al. (2008) which acknowledged the fact that students personal attitude, communication, work attitude, and leadership skills improved after undergoing IT. Rahman et al. (2009) further admonished students to prepare themselves and improve their skills before they graduate. Connor and Shaw (2008) conceding to students' poor communication skills also emphasized that IT helps to develop students' communication skills that include daily interaction within the working environment and technical writing. Other studies also view IT as a positive developmental experience for university students to improve their leadership skills (Wasonga and Murphy, 2006), knowledge in information technology, time management, communication skills and teamwork (Mihail, 2006). Rahman et al. (2009) stated that employers provide the students with hands-on-the-job experience which accelerate the trainee's progress and hands-on knowledge.

\section{Perceptions on performance during indus-} trial training

Respondents were asked to evaluate their performance during IT on 20 performance criteria. Mean scores of all the performance criteria, except three- 'ability to communicate with the public', 'negotiation skills' and 'independence'

Table 3: Mean scores, standard deviations and mean score gaps of students' satisfaction

\begin{tabular}{|c|c|c|c|c|c|c|}
\hline \multirow[b]{2}{*}{ Aspect } & \multirow[b]{2}{*}{ Attribute } & \multicolumn{2}{|c|}{ Before training } & \multicolumn{2}{|c|}{ After training } & \multirow{2}{*}{$\begin{array}{l}\text { Mean } \\
\text { Score Gap } \\
\text { (B-A) }\end{array}$} \\
\hline & & $\begin{array}{l}\text { Mean } \\
\text { score (A) }\end{array}$ & $\begin{array}{l}\text { Std. } \\
\text { Dev }\end{array}$ & $\begin{array}{l}\text { Mean } \\
\text { score (B) }\end{array}$ & $\begin{array}{l}\text { Std. } \\
\text { Dev }\end{array}$ & \\
\hline \multirow{5}{*}{$\begin{array}{l}\text { Personal } \\
\text { attitude }\end{array}$} & Self confidence & 1.70 & 0.752 & 4.27 & 0.502 & 2.57 \\
\hline & Self esteem & 1.92 & 0.759 & 4.36 & 0.566 & 2.44 \\
\hline & Curiosity & 2.33 & 0.697 & 4.63 & 0.484 & 2.30 \\
\hline & Punctuality & 2.27 & 0.713 & 4.48 & 0.494 & 2.21 \\
\hline & $\begin{array}{l}\text { Self and time } \\
\text { management }\end{array}$ & 2.26 & 0.754 & 4.38 & 0.488 & 2.12 \\
\hline \multirow{3}{*}{$\begin{array}{l}\text { Commu- } \\
\text { nication }\end{array}$} & Oral communication & 1.76 & 0.843 & 4.47 & 0.502 & 2.71 \\
\hline & Written communication & 1.88 & 0.837 & 4.55 & 0.500 & 2.67 \\
\hline & Discussion skills & 1.99 & 0.805 & 4.57 & 0.498 & 2.57 \\
\hline \multirow{7}{*}{$\begin{array}{l}\text { Work } \\
\text { attitude }\end{array}$} & Subject knowledge & 2.34 & 0.684 & 4.72 & 0.451 & 2.38 \\
\hline & $\begin{array}{l}\text { Adaptable with } \\
\text { environment }\end{array}$ & 2.27 & 0.728 & 4.54 & 0.502 & 2.27 \\
\hline & Problem solving skills & 2.32 & 0.694 & 4.58 & 0.513 & 2.26 \\
\hline & Leadership & 2.25 & 0.721 & 4.52 & 0.523 & 2.25 \\
\hline & Teamwork & 2.24 & 0.732 & 4.49 & 0.524 & 2.25 \\
\hline & $\begin{array}{l}\text { Ability to work } \\
\text { independently }\end{array}$ & 2.23 & 0.697 & 4.46 & 0.496 & 2.23 \\
\hline & $\begin{array}{l}\text { Ability to work under } \\
\text { pressure }\end{array}$ & 2.21 & 0.749 & 4.39 & 0.501 & 2.18 \\
\hline
\end{tabular}

The one sample t-test $(p=0.05)$ showed that there is a significant difference between mean scores of each attribute before and after undertaking $I T$ 
were found to be significantly greater than the neutral score of $3.00(p=0.05)$ when the t-test was applied (Table 4). Thus, the respondents were of the view that they were satisfied with their ability to apply knowledge gained from the classroom to the world of work, interact well within the work environment, and carry out instructions satisfactorily. The respondents also regarded their performance on other 14 performance criteria as satisfactory (Table 4).
They were, however, not satisfied with their ability to communicate with the public, their negotiation skills and their independence.

\section{Perceptions on monitoring of industrial training}

The results showed that majority (53\%) of the respondents did not submit any IT report to their departments. The remaining $47 \%$ who submitted reports claimed that they were not

Table 4: Respondent's performance during industrial training

\begin{tabular}{llll}
\hline Performance Criteria & Mean & Std. D & Rank \\
\hline Ability to apply knowledge & 3.98 & 0.838 & 1 \\
Ability to interact well & 3.86 & 0.944 & 2 \\
Ability to carry out instructions satisfactorily & 3.84 & 0.929 & 3 \\
Adequate background knowledge & 3.80 & 0.833 & 4 \\
Professionalism and work ethics & 3.78 & 0.959 & 5 \\
Ability to function as a team player & 3.70 & 1.066 & 6 \\
Listening skill & 3.68 & 1.119 & 7 \\
Ability to extract information & 3.66 & 0.986 & 8 \\
Disciplined and motivated & 3.65 & 1.053 & 9 \\
Ability to function as a leader & 3.64 & 1.001 & 10 \\
Lifelong learning & 3.60 & 1.053 & 11 \\
Ability to express ideas (oral) & 3.57 & 1.020 & 12 \\
Social and multi-racial awareness & 3.51 & 1.114 & 13 \\
Ability to make decision & 3.48 & 0.908 & 14 \\
Environmental awareness & 3.45 & 0.965 & 15 \\
Ability to express ideas (written) & 3.39 & 1.099 & 16 \\
Non-Verbal skill & 3.30 & 0.946 & 17 \\
Ability to communicate with public & $* 3.27$ & 1.070 & 18 \\
Negotiation skill & $* 3.25$ & 0.979 & 19 \\
Independence & $* 3.10$ & 1.070 & 20 \\
\hline
\end{tabular}

$*$ The $t$-test showed that the mean score of the performance criteria is not significantly greater than $3.00(p=0.05)$ 


\section{Ayarkwa et al.}

obliged to do so, indicating lack of serious monitoring systems to ensure that students undertake IT. Thus, although students are expected to benefit from IT, the absence of an effective monitoring system may affect their seriousness with the training. For IT to achieve the desired impact, training monitoring systems had to be quite effective (Bansal et al., 2010). Effective monitoring provides confidence in the students that the teaching departments support them and are ready to extend a helping hand to tackle various bottlenecks that come their way during industrial training (Bansal et al., 2010). Monitoring also helps to check non-serious students by putting them on the right track.

\section{Challenges of industrial training}

About thirty-four percent (34\%) of the respondents considered the current method of placement to be stressful. Some challenges students encountered during IT were identified to include 'improper supervision', 'no remuneration', and 'unprofessional or mundane tasks' (Fig. 6). The stressful nature of placement procedure for IT is in line with findings of Pillai and Yusoff (2007).

On possible measures to overcome the above challenges, the respondents were of the opinion that their teaching departments should contact the appropriate IT organization to arrange for placement for all students to undergo industrial training. They also suggested that in addition to providing lists of organizations in good standing for students to choose from, their departments should liaise with the IT organizations to ensure that IT was well structured and beneficial to them. They further suggested the introduction of strict and effective monitoring systems to enforce IT and provide confidence in the students.

\section{CONCLUSION AND RECOMMENDA- TIONS}

The student-respondents agreed that "exposure to the real working environment" and "increase in job prospects" were among the major factors motivating them to undertake industrial training. Industrial training provides benefits such as job prospects, more confidence in terms of job qualification, and more knowledge and guidance in job selection after graduation. It also significantly improves the students' performance on personal attitude, work attitude and communication skills. Their selfconfidence, oral communication skills and subject knowledge significantly improved after training. The students were satisfied with their ability to apply knowledge gained from the classroom to the world of work, interact well within the work environment, and carry out instructions satisfactorily during IT. The results, however, have shown that the major contribution of the teaching departments to industrial training has been the issuance of introductory letters to prospective trainees, and most of

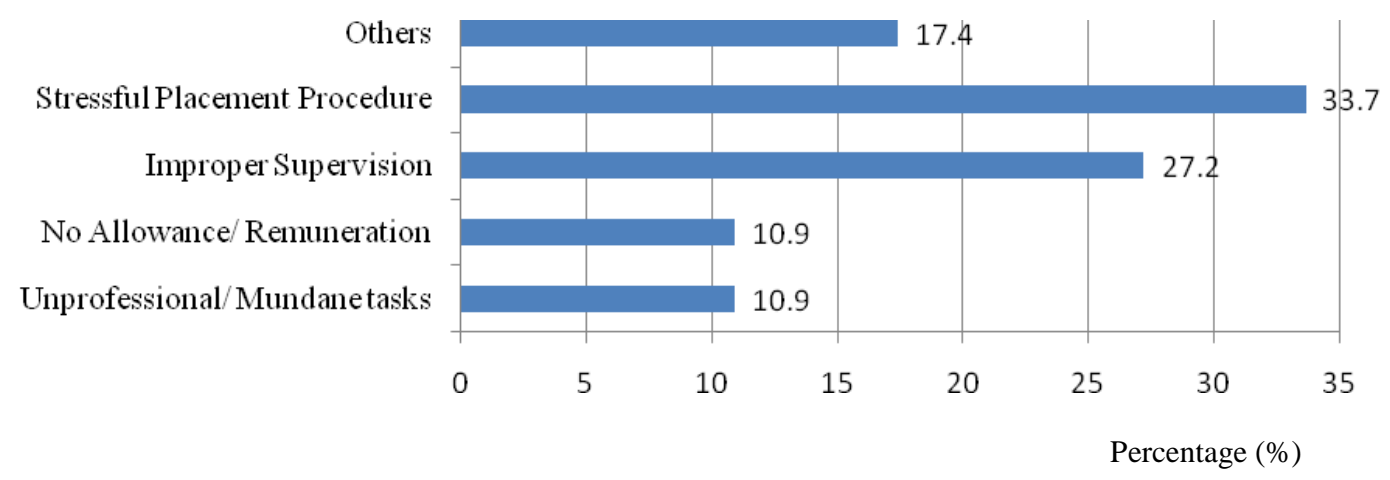

Fig. 6: Challenges encountered by students 
the student-respondents were dissatisfied with the current placement method. There was also no serious monitoring system in place to ensure that students undertake IT.

Stressful placement procedure, lack of proper supervision and financial strain on students were some of the perceived challenges to industrial training and on the basis of these, it is recommended that: educational institutions establish industrial training liaison offices to facilitate, manage and monitor the procedures involved in the placement of industrial trainees. Also educational institutions should make industrial training compulsory and training reports should be assessed and graded as part of students' overall marks. Educational institutions should institute effective monitoring systems for industrial training such as site visits, in order to enhance the effectiveness of industrial training. There is the need to have educational institutions foster linkages with industry to bridge the gap between the academia and the employer, in this case the Ghana Employers Association, in order to ensure that industrial training is well structured and beneficial to students and also the training organization.

\section{REFERENCES}

Bansal, V. K., Grover, S. and Ashok, K. (2010). Feedback on students industrial training for enhancing engineering education quality: a survey based analysis, International Journal of Engineering Science and Technology, 2 (9): 4807-4816.

Callanan, G. and Benzing, C. (2004). Assessing the role of internships in the career-oriented employment of graduating college student, Education \& Training, 46(2): 82-89.

Chileshie, N. and Haupt, T. C. (2006). Industry and Academia; Perceptions of Construction Management Education. The Case of South Africa. Available online, http:// www.cebe.heacademy.ac.uk/news/events/ beecon2006/pdf/p14-Nicholas Chileshe.pdf. [Accessed 18 ${ }^{\text {th }}$ April 2009]
Connor, H. and Shaw, S. (2008). Graduate Training and Development: Current trends and Issues, Education \& Training, 50 (5): 357-365.

Duodu, A. (2006). TVET in Ghana, A core study-Technical and vocational education division, Ghana education service ministry of education and sports, Accra, Ghana.

Fallows, S. and Steven, C. (2000). Integrating Key Skills in Higher Education, London, United Kingdom.

Garavan, T. N. and Murphy, C. (2001). The cooperative education process and organizational socialization: a qualitative study of students' perceptions of its effectiveness. Education \& Training, 43: 281-302.

Gill, A. and Lashine, S. (2003). Business education: a strategic market-oriented focus, The International Journal of Education Management, 17(5): 188-94.

Haupt, T. C. (2003). Student Attitudes towards Cooperative Construction Education Degree Level Skills for Construction and Surveying Students Experiences. The Australian Journal of Construction Economics and Building, 3(1): 31-42.

Mihail, D. M. (2006). Internships at Greece Universities: An exploratory study, Journal of Workplace Learning, 18 (1): 28-41.

Moser, C. A and Kalton, G. (1993). Survey Methods in Social Investigation, 2nd ed., Dortworth, Aldershot, England.

Nambudiripad, K. B. M. (2003). On Designing a Curriculum for Undergraduate Engineering Degree. The Indian Journal of Technical Education, 6 (3): 18-28.

Osman, S. A., Omar, M. Z., Kofli, N. T., Mat, K., Darus, Z. M. and Rahman, M. N. A. (2008). The importance of Industrial Train- 


\section{Ayarkwa et al.}

ing: Students' Perception in Civil Engineering Sector. Proceedings of the 7th WSEAS International Conference on Education and Educational Technology (EDU'08), 121-125.

Pillai, S. and Yussof, M. (2007). The Student Industrial Training Programme: Issues and Challenges. World Association of Corporate Education, 15th World Conference on Cooperative Education, June 26, Singapore.

Rahman, M. N. A., Omar, M. Z., Kofli, N. T., Mat, K., Osman, S. A. and Darus, Z. M.
(2009) Assessment of Engineering Students Perception after Industrial Training Placement, European Journal of Social Sciences, 8 (3): 420-431.

Teoh, S. (2006). Industry Explores Internship Issues. In The Star Online, http:/startechcnetral/tehc/story. [Accessed 18 ${ }^{\text {th }}$ April 2009]

Wasonga, T. A. and Murphy, J. F. (2006). Learning from tacit knowledge: the impact of the internship, International Journal of Educational Management, 20 (2): 153-163. 